\title{
4 足步行機械の踏み換え步容に関する研究
}

\author{
広 瀬 茂 男* 横 井一 仁**
}

4 足歩行機械が潜在的に有する高い移動性を発揮してゆくためには，4 足歩行機械の多彩で効率的な歩容生成 法を明らかにしてゆくことが必要である. 本研究は， 4 足歩行機械が，任意の 4 脚立位状態から，任意の 4 脚立 位状態に遷移する歩容を踏み換え歩容と定義し, そのらち特に重心が遷移前後で移動しないものを静止踏み換え 歩容と呼びその生成原理を理論的に解析し, シミュレーションにより妥当性を検証する. このような踏み換え歩 容は, 歩行機械が望みの立脚姿勢で静止し作業を行なら場合, またある歩容パターンから他の歩容パターンに遷 移するとき等に不可欠のものである.

検討の結果, 最大 6 回の踏み換方動作を行なえばどのような姿勢への静止踏み換え歩容も100\% 可能なこと, それ以下の回数の踏み換え動作については, 重心移動なしの 4 回の踏み換え動作で $25 \%$, 重心移動を含めると 95 \%, 重心移動を含む 5 回の踏み換え動作では $99 \%$ 以上の静止踏み換え歩容の実現確率があることを示す. また それらの最適な生成法も明確化する.この妥当性は計算機シミュレーションで確認するとともに，筆者らがすで に試作した 4 足歩行機械モデル TITAN III の歩行実験により検証する.

\section{1. ま え がき}

4 足歩行機械が潜在的に有する高い移動性を発揮して ゆくためには，4足歩行機械の多彩で効率的な歩容生成 法を明らかにしてゆくことが必要である. 筆者らは, こ のような観点から 4 足歩行機械の 歩容制御について, これまでに「基準旋回歩容」”や基準収束型適応歩 容」23) などの基本的歩容決定法について論じてきた.

しかしながら， 12 自由度を有する 4 足歩行機械は，こ れら以外にもはるかに大きな歩容の選択可能性を内含し ており，4足歩行機械の適応的で滑らかな歩行を実現す るためにはより多面的な検討が必要となる．たとえば, 歩行機械は単に連続的な歩行動作を行ならだけでなく， 停止して作業を行ならことがかならず必要となるが, こ の歩行終了時には足を望みの, 安定で作業しやすい 4 脚 支持位置に運ぶ動作が行なえなければならない，また歩 行中でも，基準収束型適応歩容の基本となる基準歩容を 変更する際には基準歩容が切り換わる遷移的な区間が生 ずる．従来の歩容決定アルゴリズムは基準歩容が連続す ることを前提とし，予測的な歩容決定を行うものである ためこのままでは，連続的な歩行は不可能になる場合る 生ずる.こらした状況では，切り替兄前後の歩容を結合 する特別の歩容決定法が必要である.

原稿受付 1986 年 1 月 23 日

* 東京工業大学工学部 $* *$ 機械技術研究所ロボティクス部
そこで本研究では，これらの状況で必要となる新しい 歩容概念として「踏み換兄歩容」をあらたに定義し，そ の生成原理についての検討を行ならことにする.

\section{2. 解析のための準備}

踏み換光歩容の生成アルゴリズムを論じていくために,
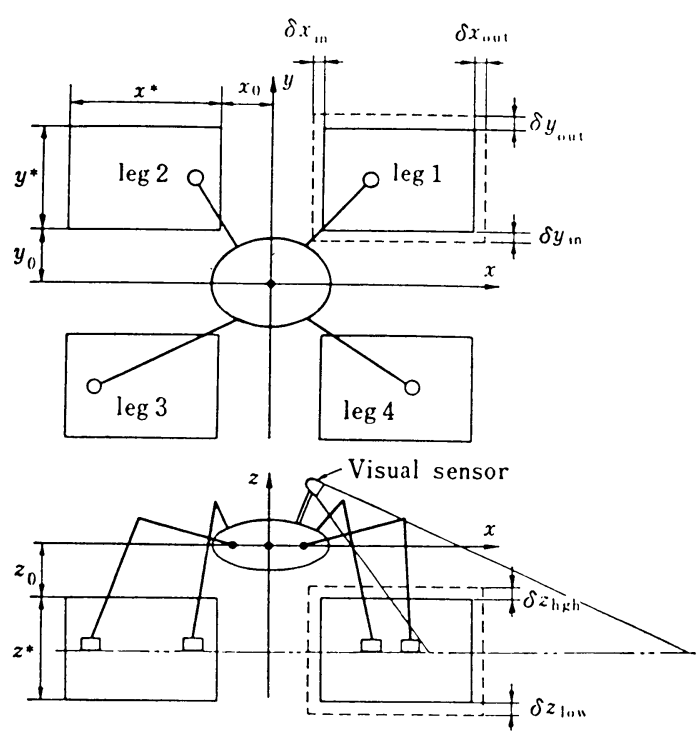

Fig. 1 The dimensions of reachable area. The reachable areas for control (solid line) are set smaller than mechanical limitation (dotted line). 


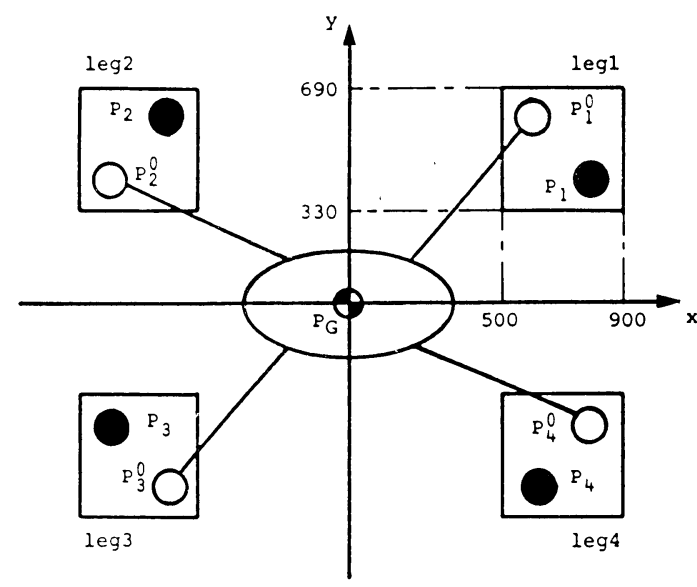

Fig. 2 Notations and dimensions for the standing posture transformation analysis

いくつかの準備を行なう.

\section{1 主要記号の設定}

$x_{0}, y_{0}, x^{*}, y^{*}:$ Fig. 1 に示す脚の可動範囲を示すパ ラメータ（正值）

$\delta x_{\text {in }}, \delta x_{\text {out }}$, 機構的可動範囲と解析で用いるソフ

$\delta y_{\text {in }}, \delta y_{\text {out }}$ : トウェア上の可動範囲との偏差幅 (Fig. 1 参照)

$s \quad:$ 安定余裕 4

$P_{i}{ }^{\circ}, i^{\circ} \quad:$ 脚 $i$ の初期位置 (図では○印で示す)

$P_{i}, i \quad:$ 脚 $i$ の目標位置(図では○印で示す)

$P_{\imath}^{*}, i^{*}:$ 脚 $i$ の中間位置(図ではの印で示す)

$s(i, j, k, l)$ : 脚 $i, j, k, l$ による 4 脚支持状態

$\Delta(i, j, k) \quad:$ 脚 $i, j, k$ による 3 脚支持状態

$P_{G} \quad:$ 胴体重心位置(図では\$印で示す)

$L(i, G) \quad$ : 脚 $i$ の位置 $P_{i}$ と重心位置 $P_{G}$ を通る 直線

$A_{i}(j, S-k): L(j, G)$ によって 2 分割された脚 $i$ の可動範囲のらち脚 $k$ 側である 領域(Fig. 3 参照)

\section{2 対象とする歩行体モデル}

歩行体として想定する歩行機械モデルは, Fig. 1 のよ らに 4 脚とする. そして, この歩行機械の座標系として は, 重心（以降「重心」とは胴体の重心 $G$ を示すこと にする）を原点とし, 胴体前後方向に $x$ 軸, 左右方向に $y$ 軸, 上下方向に $z$ 軸を右手系でとるものとする. 解析 に当たっての座標系は, 初期重心位置での重心座標系を 基本的に用いる. 脚は, Fig. 1 のように $x y$ 座標での象 限に合わせて 1〜4 脚と名付ける. 制御上の脚可動範囲 は, 重心に対して対称とし, その形状はFig. 1 のように $x_{0}, x^{*}, y_{0}, y^{*}$ で示される長方形とする. ただし, 歩行機
械の機構的可動範囲は, Fig. 1 の破線に示すように $x y$ 方向とも $\delta x_{\text {out }}, \delta x_{\text {in }}, \delta y_{\text {out }}, \delta y_{\text {in }}$ だけ制御上の可動範囲 より余裕を持って大きいものとする. なお, 以降「脚可 動範囲」と言うときは, 制御上の脚可動範囲の方を示す ことにする.

\section{3 踏み換え歩容の定義}

「踏又換え歩容」とは以降，次のよらに定義する.

「歩行機械を絶対座標系で設定された一つの立位状態 から他の立位状態へ遷移させる歩容. ただしここでいら， 立位状態とは歩行機械の胴体重心の位置と姿勢, および 速度そして全 4 脚の支持脚パターンを規定するものであ る.」

つまり, 対象とする踏み換え歩容とは, 歩行動作の開 始と終了の状態に注目して定義された歩容であり, 従来 の連続歩行を前提とした基準旋回歩容等とは異なるカテ ゴリーに属する歩容概念であると言える.よってもしも

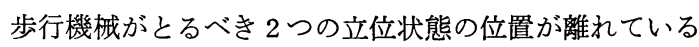
場合には, その間の踏み換え変容の過程では従来検討さ れた基準旋回歩容がとられることも発生することになる. 比喻的にさらに説明すると, 走り高飛びの助走において 重要なのは, 助走開始後最適な踏み切り位置と姿勢々し て速度をとることである. 踏み換え歩容とはこのような 目的で行われる「助走」といら一つのセットとしての歩 容を意味することになる.

踏み換え歩容はこのようにかなり広い歩容概念であり， その歩容の最適な生成原理等については今後多面的な研 究がなされなければならない、本研究では, このうちの 最も基本的な歩容を特に「静止踏み換え歩容」と呼び, 以下のように定義する.

「踏み換劣歩の動作開始時と終了時の立位状態にお いて, 胴体重心が静止しており, かつその絶対座標系に おける位置, 姿勢が変動しない歩容.」

つまり, 静止踏み換え歩容は, Fig. 2 のように, 重心 の位置と姿勢を歩容の 前後で変化させず, 各脚 $i(i=$ 1４）の位置を踏及換学前の初期位置 $P_{i}{ }^{\circ}$ から踏み換元 後の目標位置 $P_{\imath}$ へ変化させる歩容であるといらことに なる. 本論文での以降の議論は静止踏み換え歩容の解明 のみを行らこととする.

\section{4 解析のための設定条件}

歩行体の性能および基本的な歩行機能については以下 のような設定を設ける.

（1）歩容中, 重心は一定の高さに固定され, 足先は $x y$ 平面上での 2 次元運動のみを行なうものとする. 実 際の踏み換え動作では，たとえ平坦地であったとしても 脚を踏み換えるためには，足先を若干地面から浮かせて 動かさなければならない.つまり踏み換え動作の始めと 
終わりに二方向の運動が不可分に含まれる。しかし本研 究では簡単のためにこの運動を無視し，足先は地表面す れすれに運動すると仮定する.

（2）移動環境としては，最も基本的な完全平坦地を 想定する.

（3）静的安定の 測度としては，安定余裕（stability margin） $s^{4)}$ つまり，「胴体重心から支持脚多角形の辺ま での最小距離」の概念を用いる. そして, 静的安定条件 は安定余裕が非負つまり $s \geqq 0$ のときのみ満足されると する. なお， $s=0$ でも安定と考学ることは実際の歩行 機械では足裏に有限の面積を持つことから実際的な仮定 である. 後述する TITAN III です $s=0$ で安定である ことは実験的に確認されている.

（4）踏み換元の過程で胴体の姿勢（方向）は変立な いものとする．ただし重心の移動は必要に応じて考慮す ることとする.

\section{5 解析に用いる基本特性}

静止踏み換兄歩容解析に特有で重要な基本特性をあら かじめ明確化しておく.

それは, 脚可動範囲の対称性から任意の脚，たとえば Fig. 3 の場合には脚 1 に対し, その位置 $P_{1}$ と重心位置 $P_{G}$ を通る直線 $L(1, G)$ は, 必ず対角脚である脚 3 の脚 可動範团を $2 つ の$ 領域に分割するという特性である. 以 降この脚可動範囲内の分割領域については, 上述の例で 言らと脚 2 側である領域を $A_{3}(1, S-2)$, 脚 4 側である領 域を $A_{3}(1, S-4)$ の上うに呼称する. な拉, Fig. 3 の脚 2 の上らに脚位直 $P_{2}$ が脚可動範囲の角に存在したとして

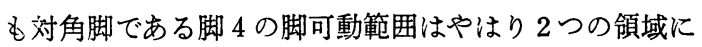
分割することが可能である.ただしこの場合一方の領域 は面積ゼ口の点となる. より現実的には, 脚の機構的可 動範囲 Fig. 1 に示したように余 裕幅を持っているので，その領 域を利用すればよい。

このように領域を 2 分割でき る特性は, 静的安定条件を満足 する遊脚の選定に重要な意味を 有する.なぜなら同じく Fig. 3 の例で言うと, もしも脚 3 の位 置 $P_{3}$ が脚 2 側の領域 $A_{3}(1, S-2)$ に存在すれば,この状態では脚 2 の遊脚化が保証され, 脚 4 側 の領域 $A_{3}(1, S-4)$ 飞存在すれ ば, 脚 4 の遊脚化が保証される というように, この領域と遊脚 化可能脚が 1 対 1 に対応してい るからである.

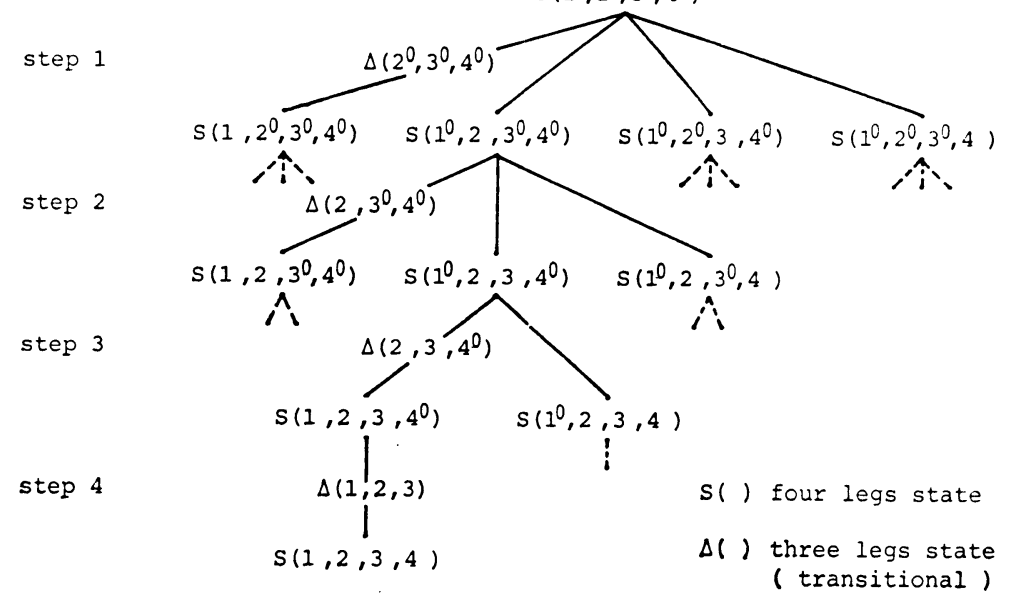

Fig. 4 State tree of standing posture transformation 


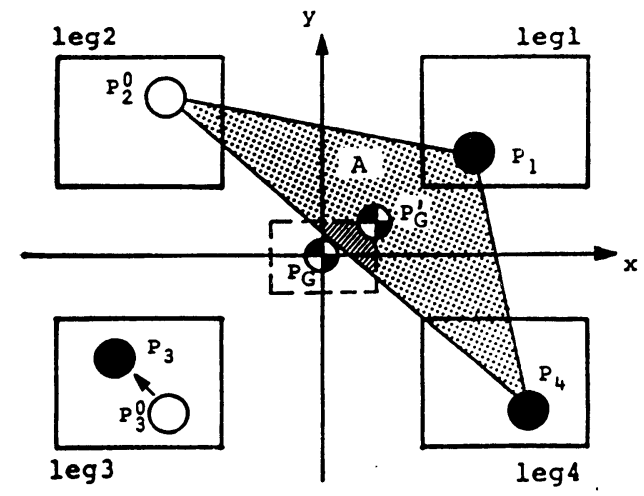

Fig. 5 The effect of transitional shift of center of gravity inside its reachable area

4 脚支持状態でのまだ踏み換えが行なわれていない脚の 数を表わす．また，各探索ごとに 1 脚ずつ踏み換えを行 ならので, その経路は $24(=4 !)$ 種類存在する.

さて，このような選択枝の中で，ある 4 脚支持状態か ら次の 4 脚支持状態へ移行し得る条件は，その間の支持 脚 3 角形が静的安定条件を満足することである.そのた め, Fig. 4 の探索木は，その静的安定条件を判定しなが ら探索してゆけばよい.

一般に，重心が対角脚を結ぶ直線上に存在するという 特殊な状態を除けば，どの 4 脚支持状態からでも，静的 安定条件を満足する支持脚 3 角形は, 必ず 2 種類存在す る.なぜなら，ぞのような 4 脚支持状態でも重心は対角 脚を結ぶ直線の必ず一方に存在する (Fig.5 参照). よ

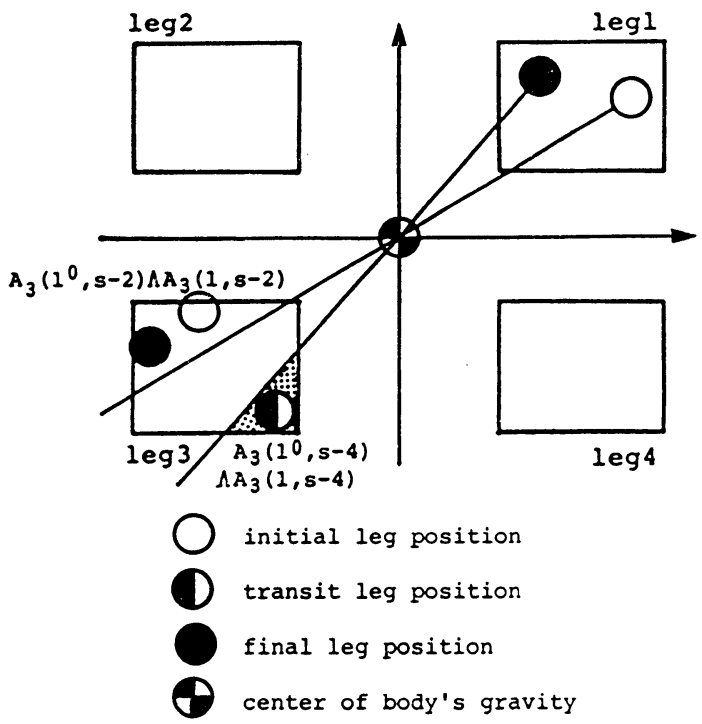

Fig. 6 The area for transit leg effective for the standing posture transformation
って, 静的安定条件を満足するように重心を含まない側 の脚を遊脚化することを 4 脚について考えれば，そのら ちの 2 脚は必ず遊脚化が可能になるからである.なお, もしも重心が対角脚を結ぶ線上に存在する場合には，そ の条件を生かした特別の踏み換え法る考えられる. しか し，ここでは重心は任意に選択される一方の支持脚 3 角 形の内部に含まれると考え，特別な取り扱いは行わない こととする.この特性によれば, 初期状態 $S\left(1^{0}, 2^{0}, 3^{0}\right.$, $\left.4^{0}\right)$ から Fig.4 の step 1 で選択できる経路は 2 種類存 在する. 以降これらの経路を $S_{1}, S_{2}$ と呼ぶ. また, step 2 で選択できる経路は， $S_{1}, S_{2}$ とも step 1 でそれぞれ 1 回だけ遊脚化可能な支持脚 3 角形を選択するのに使用し ているため $S_{1}, S_{2}$ 両者ともそれぞれ, 残り 1 種類のみ存 在する. step $3, \operatorname{step} 4$ についても同様である. 以上のこ とから，ある与えられた初期脚配置について，静止踏み 換え歩容が実現できる経路は最大でも 2 種類にすぎない ことになる.つまり，一般には 4 回の踏み換え動作で静 止踏及換光歩を完了できる可能性はかなり低いことが 予測される.

このような探索の達成可能性を定量的に評価するため, ここでは新たに踏み換えの「実現確率」という概念を定 義する．実現確率とは多量の任意に作成した脚配置につ いて，踏み換え歩容を達成できるか否かについてモンテ カルロ法的なシミュレーションを行ない，1つでも達成 できた脚配置数を $N$, 試行した全脚配置数を $N_{0}$ とした とき，N/No の值として与えるものである.なお，実際 には $N_{0}$ としては, 乱数的に発生させた 4 脚の初期状態 と目標状態の配置 1,000 ケースをとる.このような評 価基準を用いて，重心を静止したまま，4回の踏み換え 動作を行なら静止踏み換え歩容のシミュレーション実験 を行なったところ，その実現確率の值は約 $25 \%$ であっ た.

な怙, シミュレーションでは, Fig. 2 のよらな後述す る TITAN III と同等の脚可動範囲を用いたが，理論上 はこの脚可動䈇囲の数値は重要な因子ではなく脚可動範 囲が対称形でありさえすれば，この実現確率は同じにな ることが確認されている。

\section{4. 重心移動の導入}

静止踏み換え歩容の実現確率を向上するため, 次に踏 み換えの過程において重心を移動することを考える．確 率向上のためには，ほかに補助的な踏み換觉動作を加兄 5 回, 6 回と踏み換光回数を増加させる方法もあるが, それよりもまず重心を移動させながらの静止踏み換え歩 容を考えるのは，重心移動だけなら時間のかかる遊脚の 上下動の回数の増加が抑えられ高速化が計れること, 重 
心を移動可能とするだけでも大幅に静止踏み換え歩容の 実現確率が向上できる可能性のあること，などの理由か らである。

上述の第 2 の理由は，たとえば Fig. 5 の 脚配置で, 重心が $P_{G}$ で静止している場合は脚 3 は遊脚化できない が，重心が領域Aのいずれかの位置まで移動できるので あれば，脚 3 が遊脚化できることからもわかる．ただし， 常にこのように遊脚の選択枝が增えるわけではない，な ぜなら重心の可動範囲も考虑しなければならないからで ある. 重心の可動範囲は, Fig. 5 破線のように長方形領 域として与えられる.これは, 支持 3 脚の位置扣よび遊 脚の初期位置と目標位置，つをり合計 5 脚が接地状態に あると考光，それぞれによって制限された重心の移動可 能範囲の積集合である.よってもしも支持脚が朋可動範 囲の周辺部にあったりした時はこの重心の可動範囲は狭 くなってしまい，前述したような有効な領域まで重心を 移動させる動作が不可能な場合も生じてしまうわけであ る.

そこで実際に，踏み換え中に重心移動も許容される静 止踏み換えの歩容の実現確率をシミュレーション実験で 求めた.な敃重心移動を Fig. 4 の探索木の探索に含め ることは，以下のように行なう。（1）まず，ある4 脚支 持状態から次の 4 脚支持状態を探索するに当たり，ある 脚を遊脚と定めその時の重心可動範囲を算出する．次い で（2）対角脚を結ぶ対角線と重心可動範囲の 関係か らその脚が遊脚化可能か 調べる.（3）遊脚化していな い全ての脚に対して上述の探索（1），（2）を行なう, といらものである. このように重心移動を付加したアル ゴリズムによるシミュレーションの結果, 踏み換え中に 重心移動も許容される静止踏み換兄歩容の実現確率は約 95\% であった.

\section{5. 補助的な踏み換え動作の導入}

重心移動が許容される静止踏み換兄歩容を行なっても， 未だ $5 \%$ の脚配置については 4 回の踏み 換え 動作だけ では，踏み換觉が達成できないことがわかった，そこで， 次に補助的な踏み換光動作を導入するための考察を行な う.

補助的な踏み換光動作の 効果は Fig. 6 の例から 明ら かである.つまり, Fig. 6 のように脚 3 の初期位置 $P_{3}{ }^{0}$ と目標位置 $P_{3}$ が同一領域 $A_{3}\left(1^{0}, S-2\right) \cap A_{3}(1, S-2)$ 飞存 在している場合には，脚 3 と脚 1 のいずれもが踏及換え を行なったとしても，遊脚化可能な脚は共に脚 2 であり 変化しない，しかし，反対側の領域，この場合は $A_{3}$ $\left(1^{0}, S-4\right) \cap A_{3}(1, S-4)$ 飞補助的な踏み換光を行ならとす れば，今まで遊脚化できなかった脚 4 る遊脚化できるか

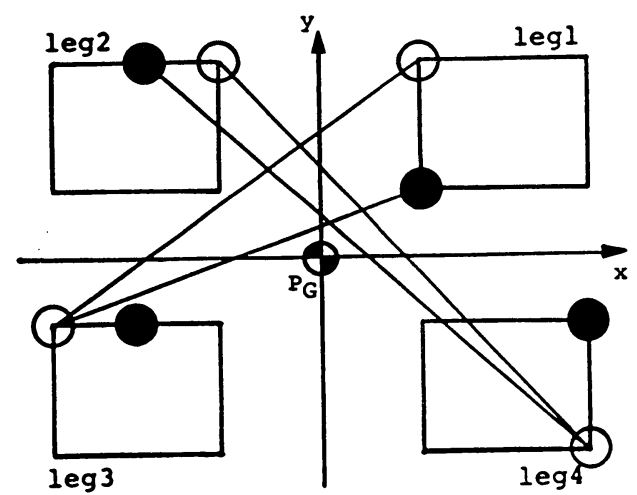

Fig. 7 A special leg disposition which requires more than two transit leg positions

らである.

この補助的踏み換元動作の実際の含め方は，Fig. 4 の 探索を拡張し，次のように行なった：それは，(1) 探索 に先立ち，まず全 4 脚を 3 つの領域に分割する.この分 割は対角側の位置に依存し，たとえば Fig. 6 の脚 3 の 例では $L\left(1^{\circ}, G\right), L(1, G)$ で分割される 3 領域となる. 次に, (2) 各脚の 3 領域について, そのうちの中間の領 域を除く 2 領域に中間位置 $P_{i} *$ をれぞれとる.（3）

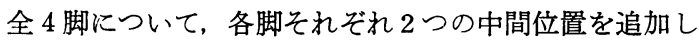
た新たな探索木を構成する.（4）中間位置の選択は 1 つの試行で 1 回のみとする，ということを前提として探 索を実行する，というるのである. な打手順（2）で，

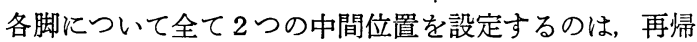
的構造を採用することによりプログラム構成の簡潔化を 計るためである．実際には，全脚合計 8 つの中間位置の らち有効なのは 4 領域に含まれるものだけであり,この ことは容易に証明される.今後探索の効率化を計るため には，これらの知見も積極的に利用すべきであろう。

以上述べたような，補助的な踏及換え動作を 1 回伴う 5 回の遊脚化を行なら静止踏み換え歩容（ただし，重心 移動も許容されるとする）の実現確率を求めたところ, その值は $99 \%$ 以上であった.

\section{6 回の踏み換え動作の導入とその完 全達成特性の証明}

前章の考察から，ほとんどの場合 5 回までの踏み換え 動作で十分であることがわかった.

しかし, Fig. 7 のよらな特殊な脚配置を考光ると, 脚 3 , 脚 4 の 2 つの脚は決して遊脚化することができない ことがわかる.この場合には，2 回以上の補助的な踏み 
換え動作が不可欠である.

ただし，高々 6 回の踏み換え動作を行なえば，どのよ らな脚配置の場合についても, 歩容中重心を静止させて いる静止踏み換え歩容が実現可能であるということは証 明できる．以下この証明を行なう。

初期状態 $S\left(1^{0}, 2^{0}, 3^{0}, 4^{0}\right)$ に打いて, 遊脚化可能な 2 脚のうち一方を脚 1 と呼び，この脚が最初に踏み換えを 行なうとする．また，この脚 1 が目標位置に着地した後 に遊脚化できる脚 1 以外の脚を脚 2 とする. そして，脚 1 の対角脚を脚 3 ，脚 2 の対角脚を脚 4 とする.このよ うに脚番号を再定義しても一般性は失われない。

この時, 脚 1 の目標位置 $P_{1}$, 脚 2 の初期位置 $P_{2}{ }^{0}$, 脚 ' 3 の初期位置 $P_{3}{ }^{0}$, 脚 4 の初期位置 $P_{4}{ }^{0}$ と直線 $L(1, G)$, $L\left(4^{0}, G\right)$ の位置関係は，どのような全 4 脚の設定位置条 件 $P_{i}^{\circ}, P_{\imath}(i=1 \sim 4)$ についても Fig. 8 (1) に示すよ らなパターンを保持する.

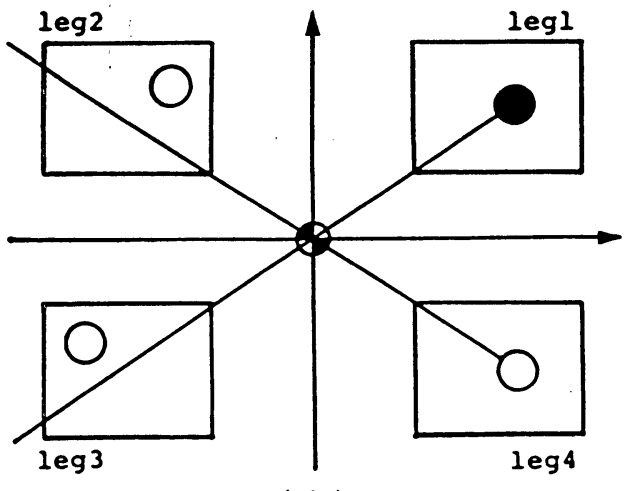

(1)

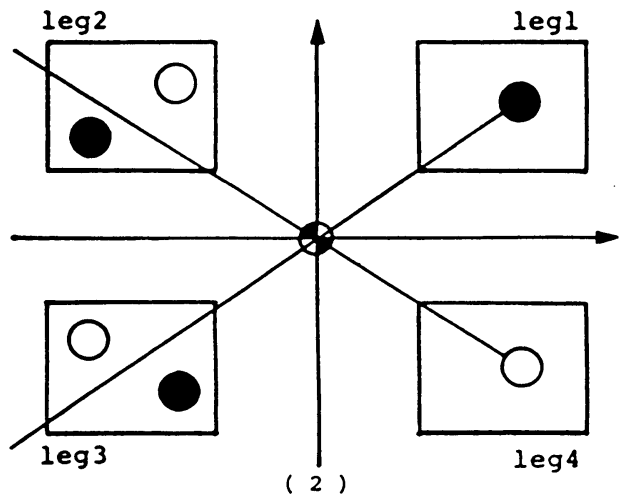

残りの脚位置についても考虑すると，全ての脚配置は， 以下の（a)，(b)，（c）の 3 分類のいずれかに分類さ れる.つまり，

(a) 脚 2 , 脚 3 の目標位置 $P_{2}, P_{3}$ が，それぞれ初 期位置 $P_{2}{ }^{0}, P_{3}{ }^{0}$ と反対側の領域 $A_{2}\left(4^{0}, S-3\right), A_{3}(1, S-$ 4) に存在する場合 (Fig. 8(2))

(b). 脚 3 の目標位置 $P_{3}$ は, 初期位置 $P_{3}{ }^{0}$ と反対側 の領域 $A_{3}(1, S-4)$ に存在するが, 脚 2 の目標位置 $P_{2}$ が, 初期位置 $P_{2}{ }^{0}$ と同一領域 $A_{2}\left(4^{0}, S-1\right)$ に存在する場合 (Fig. 8( 3 ))

(c) 脚 3 の目標位置 $P_{3}$ が, 初期位置 $P_{3}{ }^{0}$ と同一領 域 $A_{3}(1, S-2)$ に存在し, 脚 2 の目標位置 $P_{2}$ が脚可動範 囲の任意の位置に存在する場合 (Fig. 8( 4))

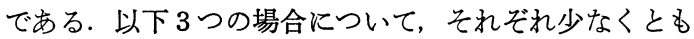
$1 つ, 6$ 回以内の踏み換え動作で静止踏み換え歩容が達 成できる踏み換え脚順序が存在することを証明してゆく

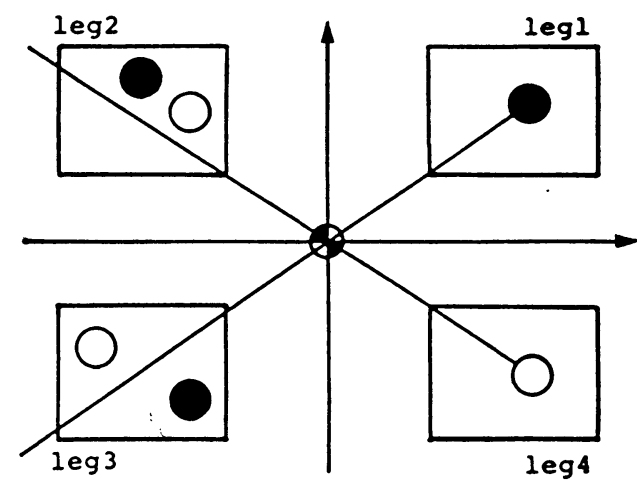

(3)

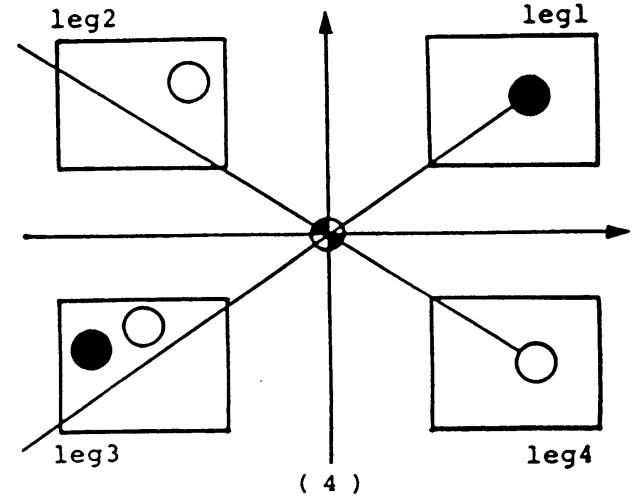

Fig. 8 Classification of standing posture transformation with fixed gravity position (1) : basic leg disposition to satisfy prescribed definitions (2), (3), (4): three specific leg dispositions 
（a）の場合は，まず脚 1 を踏み換える.すると, 脚 2 の目標位置 $P_{2}$ が初期位置 $P_{2}{ }^{0}$ と反対の領域 $A_{2}\left(4^{0}, S-\right.$ 3）に存在するため，脚 2 を踏み換えることにより脚 3 の遊脚化は保証される。. また，脚 3 の目標位置 $P_{3}$ が初 期位置 $P_{3}{ }^{0}$ と反対側の領域 $A_{3}(1, S-4)$ に存在するため, 脚 3 を踏及換えることにより脚 4 の遊脚化が保証される. このようにすることにより, 脚 1 の初期位置 $P_{1}{ }^{0}$, 脚 4 の目標位置 $P_{4}$ にかかわらず, 脚 $1 \rightarrow$ 脚 $2 \rightarrow$ 脚 $3 \rightarrow$ 脚 4 の順序の 4 回の踏及換光動作で，この脚配置については 必ず静止踏み換え歩容が実現できる (Fig.9).

(b) の場合は, 脚 2 の目標位置 $P_{2}$ が, 初期位置 $P_{2}{ }^{0}$ と同一領域 $A_{2}\left(4^{0}, S-1\right)$ に存在する為, 脚 1 , 脚 2 が遊 脚化できても，このままでは脚 3 を遊脚化することがで きない，そのため, 脚 3 の遊脚化を保証するために, 脚 4 の目標位置 $P_{4}$ にかかわらず脚 3 が遊脚化できる領域 $A_{2}\left(4^{0}, S-3\right) \cap A_{2}(4, S-3)$ に, 脚 2 の補助的な着地点であ る中間位置 $P_{2}{ }^{*}$ を配置することが必要となる。 また， 脚 3 の目標位置 $P_{3}$ が, 領域 $A_{3}(1, S-4)$ に存在するとい らことは，全脚が目標位置に存在する静止踏み換え歩容 終了時には，脚 4 の遊脚化が必ず保証されていることに なる.よって，脚 4 を最後䇥み換えるるのとする，さ らに, 脚 2 の遊脚化を保証するために, 脚 3 が初期位直 $P_{3}{ }^{0}$, 目標位置 $P_{3}$ のどちらに存在していても, 脚 2 が必 ず遊脚化できる領域 $A_{1}\left(3^{0}, S-2\right) \cap A_{1}(3, S-2)$ に脚 1 の 中間位置 $P_{1}^{*}$ を配置する.このようにすることにより， 脚 1 の初期位置 $P_{1}{ }^{0}$, 脚 4 の目標位置 $P_{4}$ にかかわらず, 脚 $1 \rightarrow$ 脚 $2 \rightarrow$ 脚 $3 \rightarrow$ 脚 $2 \rightarrow$ 脚 $1 \rightarrow$ 脚 4 の順序の 6 回の踏 み換え動作で，この脚配置については必ず踏み換え歩容 が実現できる (Fig. 10).

(c) の場合は, 脚 3 の目標位置 $P_{3}$ が初期位置 $P_{3}{ }^{0}$ と 同一領域 $A_{3}(1, S-2)$ に存在するため, 脚 2 , 脚 1 は遊脚 化できても，脚 4 の遊脚化は保証されない，そのため， 脚 4 が遊脚化できる領域 $A_{3}(1, S-4)$ に, 脚 3 の中間位 置 $P_{3}^{*}$ を配置することが必要となる. また，脚 3 の目 標位置 $P_{3}$ が領域 $A_{3}(1, S-2)$ に存在するということは, 全脚が目標位置に存在する踏み換光歩容終了時には, 少 なくとも脚 2 の遊脚化が保証されているので, 脚 2 を最 後に踏み換兄るものとする. そして, 脚 3 の遊脚化を保 証するために, 脚 4 の目標位置 $P_{4}$ にかかわらず, 脚 3 が遊脚化できる領域 $A_{2}\left(4^{0}, S-3\right) \cap A_{2}(4, S-3)$ に, 脚 2 の中間位置 $P_{2}^{*}$ を配置する. このようにすることによ り, 脚 1 の初期位置 $P_{1}{ }^{0}$, 脚 2 の目標位置 $P_{2}$, 脚 4 の目 標位置 $P_{4}$ にかかわらず, 脚 $1 \rightarrow$ 脚 $2 \rightarrow$ 脚 $3 \rightarrow$ 脚 $4 \rightarrow$ 脚 $3 \rightarrow$ 脚 2 の脚順序の 6 回の踏及換元動作で, この脚配置 については必ず踏み換えが歩容が実現できる(Fig. 11).

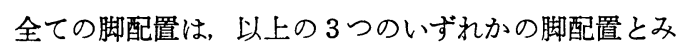
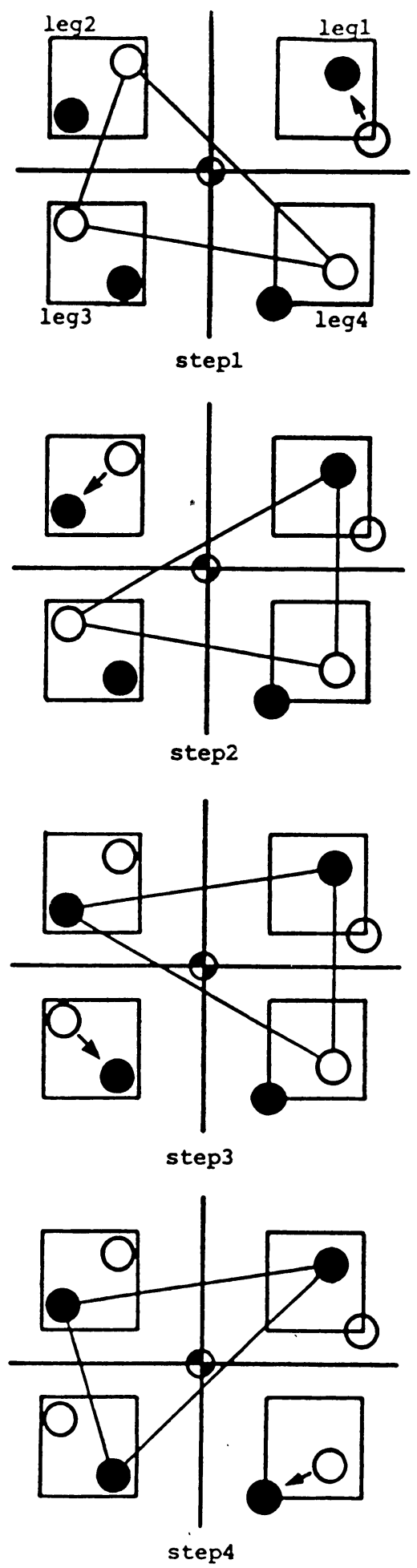

Fig. 9 The standing posture transformation corresponding to the case (2) of Fig. 8 (Four steps with fixed gravity center) 


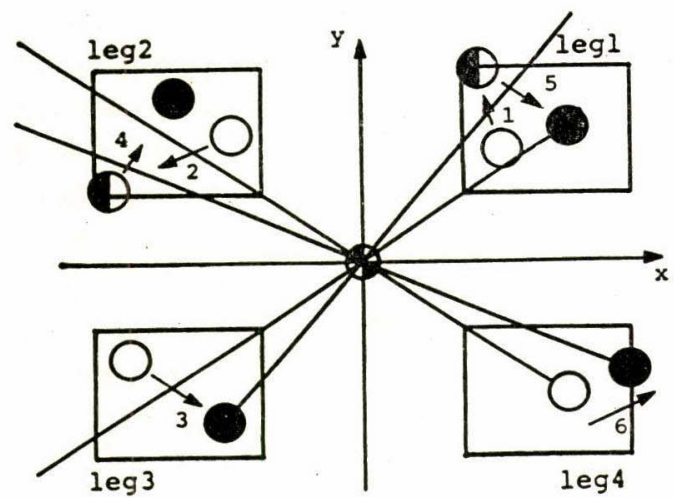

Fig. 10 The standing posture transformation corresponding to the case ( 3 ) of Fig. 8 ( $\mathrm{Six}$ steps with fixed gravity center)

なすことができるため, 最大 6 回の踏み換え動作を行な 学ば，踏み換光動作中も重心を静止させた静止踏み換兄 歩容は, 必ず実現可能であることが証明される.なお， Fig. 7 の脚配置は前述の (c) の例に相当する. よって, Fig. 7 のような特異な例でも踏み换光動作を 6 回行な元 ば静止踏及換光歩容は実現でさるわけである。

\section{7. 最適な静止踏み換え歩容についての考察}

以上考察した静止踏み換え歩容について, 最適性の観 点から改めてその歩容選択手順の検討を行なう. 最適条

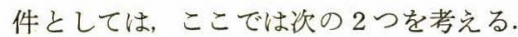

最適条件 1

「静止踏み換え歩容の動作時間が最小となる条件」 最適条件 2

「静止踏み換觉歩容中の重心の摇動が最小となる条件」 このらち最適条件 1 は具体的には, 以下の 2 つの条件 に帰着して考学てもよいと思われる。つまり，

最適条件 1-A一脚の踏及換光動作回数の最少化

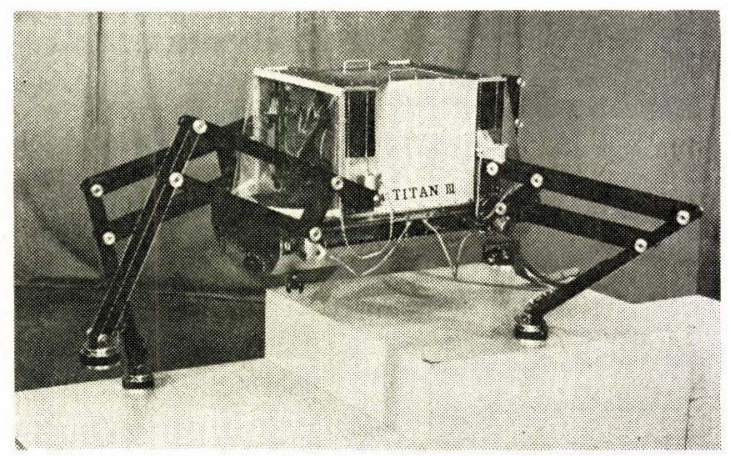

Fig. 12 The constructed walking vehicle model TITAN III

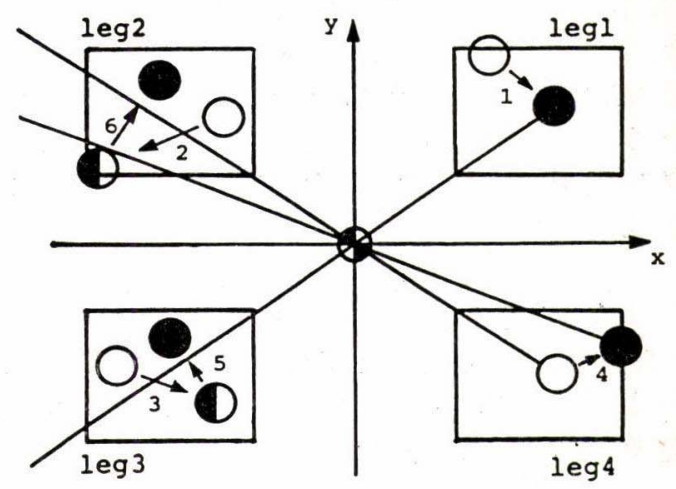

Fig. 11 The standing posture transformation corresponding to the case (4) of Fig. 8 (Six steps with fixed gravity center)

最適条件 1-B-4 脚支持状態における重心移動量の最 小化

である。

このらち, 最適条件 1-A は, 3.2 節で述べたように 時間のかかる遊脚の上下動を含む補助的な踏み換光動作 を, 最小限の回数にしょうとする条件であり, 最適条件 1-B は, 重心移動を行なら場合には, その時間を最短に するといら条件に対応する. なおここで 4 脚支持状態に 限定したのは， 3 脚支持状態での重心移動は, 本来の踏 み換光動作中に平行して行なえるため，よほぞその間の 重心移動量が大きくない限り, 重心移動動作は全踏み換 党動作の実行時間には影響を及ぼさないが，4 脚支持状 態における重心移動は，踏み換兄動作とは別に独立して 行なわなければならないからである。

最適条件 2 は, 具体的には静止踏み換光歩容の開始か ら終了までの重心の移動量の総和, 重心移動方向の変更 回数などに関保する. このらち重心移動方向の変更回数 は, 重心の移動軌跡をなめらかにすることなぞで, 摇動 に直接影響しない場合も考克られる。ここでは近似的に， 重心の移動量の最短化のみを最適条件 2 の測度として考 えておくことにする.

これら，3つの最適条件の優先順位は，1-A, 1-B, 2 の順であり, 上位の条件が同じものに限り, 下位の条件 を考虑すればよいと思われる. 実際に構成した静止踏み 換穴歩容生成用のプログラムにおいいても，まず 4 回の重 心移動を伴う静止踏及換光歩容について, Fig. 4 の探索 木で縦型探索を行ない, 可能な歩容のうち重心の移動距 離が最小のるのを選択する. 4 回の静止踏み換光歩容が 不可能な場合には, 5 回の重心移動を伴う踏み換壳動作 のための探索木を新たに生成し, 可能な歩容のうち重心 の移動距離が最小のものを探査している. なお,ここで 
広瀬茂 男

は探索の効率の向上を計るため, 積極的に枝刈り手法を 導入している. 通常の脚配置では, これでほとんど静止 踏み換え歩容は実行できる. しかしこれでも不可能な 特別の場合には, さらに場合分け手法に基づく，6回の 踏み換觉動作による静止踏み換え歩容の生成を行なえば よい.

\section{8. 試作歩行機械モデルによる歩行実験}

誘導した踏み換え歩容を Fig. 12 に示すような 4 足歩 行機械モデル TITAN III によって実際に実現した，目

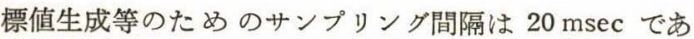
る.

なお， TITAN III は脚全長 $1.2 \mathrm{~m}$, 全質量 $80 \mathrm{~kg}$ で あり，全 12 個のリニアアクチュエータをPC-9801によ るソフトウェアサーボによる制御で歩行をおこなってい る.

使用言語はC言語を用いており，インプリメントした 踏み換劣歩容の生成と, その後の脚の制御を含むプログ ラムの大ささは約 $40 \mathrm{~K}$ であった. ただし，ここでは 6 回の踏み換え動作のための生成プログラムはほとんど使 用されないため省略している. 実験の結果 TITAN III は, 与えられた任意の 4 脚支持脚位置から任意の 4 脚目 標支持脚位置へ，最適な踏み換え歩容を自動的に生成し， 動作できることを確認した. な㧊，踏み換え歩容生成の 時間は，歩容探索の難易度に大きく依存するが最短で数 msec 最長で $1 \mathrm{sec}$ 程度であり, 全 4 脚の踏み換え実行 時間は平均 $8 \mathrm{sec}$ 程度であった.

\section{9. あとがき}

本研究においては，4足歩行機械の踏及換え歩容のら
横 井一仁

ち特に静止踏み換光歩容に注目し，その最適な歩容生成 法を論じた. その結果, 最大 6 回の踏み換え動作を行な えばどのような姿勢への静止踏又換え歩容も100\% 可能 なこと, それ以下の回数の踏み換壳動作については, 重 心移動なしの 4 回の踏み換觉動作で 25\%, 重心移動を 含めると $95 \%$, 重心移動を含む 5 回の踏み換え 動作で は $99 \%$ 以上の静止踏み換劣容の実現確率があること を示した．またその具体的生成法を明らかとした，それ らの妥当性は, 計算機シミュレーションで確認すると ともに，筆者らか゚すでに試作した 4 足歩行機械モデル TITAN III の歩行制御実験により検証した。

今後, 本研究の考察を基礎にして, 踏み換え歩容の前 後で重心移動を行ならことも含む，より効率的な踏み換 え歩容の生成アルゴリズムも誘導できよう，また，踏み 換え歩容を「基準旋回歩容」や「基準収束型適応歩容」 などの基本的な歩容決定法と組み合わせることにより， さらに汎用的で実用的な歩容決定アルゴリズムが誘導で きるものと思われる。

最後に，本研究を行ならに当たり御協力いただいた梅 谷陽二教授に深甚な感謝の意を表する.

\section{参 考 文 献}

1）広瀬，菊池，梅谷，“ 4 足歩行機械の基準旋回歩容”日本 ロボット学会誌, Vol.2-6, pp. 545-556, 1984

2）広瀬，福田，菊池 “4 足歩行機械の制御システム”日本 ロボット学会誌，Vol.3-4，pp. 304-323，1984

3) Hirose, S., "A Study of Design and Control of a Quadruped Walking Vehicle", Int'l Journal of Robotics Research, Vol.3-2, pp.113-133, 1984

4) McGhee, R. B., and Frank, A. A., "On the stability properties of quadruped creeping gait", Math. Biosci., Vol.3-3, pp.331-351, 1968

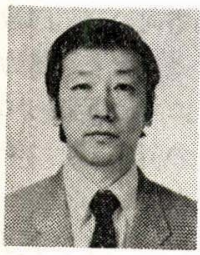

\section{広瀬茂男 (Shigeo HIROSE)}

昭和 22 年 12 月 6 日生れ，51 年東京 工業大学制御工学専攻博士課程卒, 工学博 士，同年同学機械物理工学科助手，54年同 学助教授, 現在に至る. ロボット工学, パ イオメカニズムの研究に従事.

（日本ロポット学会正会員）

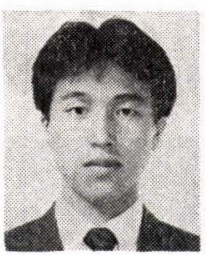

横井一仁 (Kazuhito YOKOI)

昭和 36 年 11 月 11 日生れ, 59 年名古 屋工業大学工学部機械工学科卒, 61 年東京 工業大学大学院理工学研究科機械物理工学 専攻修士過程修了, 同年通産省工業技術院 機械技術研究所入所. 現在ロボティクス部 感覚機構課. 計測自動制御学会会員.

（日本ロポット学会昭和61年度学生会員） 


\title{
The Standing Posture Transformation Gait of the Quadruped Walking Vehicle*
}

\author{
Shigeo HIROSE** Kazuhito YOKOI***
}

\begin{abstract}
In order to endow the walking vehicle with high mobility, analytical study to generate miscellaneous and effective gait have to be investigated. The paper defineds a standing posture transformation (SPT) gait as the gait which transfers the walking vehicle from arbitrary four legs standing posture to other four legs standing posture, and makes theoretical consideration for the proper generation of the SPT gait. The theory is verified by computer simulation. The SPT gait is indispensable to generate, for example, approaching motion of the walking vehicle to the working site in order to fix itself in a certain desireable posture, or smooth transfer walking from any transitional posture of a gait to another gait.

As a result of the analysis and simulation study, it is shown that any SPT gait can be executed with the possibility of $100 \%$ if the six times leg motion is allowed. In case of the leg motion six times, it is shown that the $25 \%$ is possible for the SPT gait with four times less than leg motion and with no shifting motion of the body's center of gravity; the $99 \%$ is possible for the SPT gait with five times leg motion and with shifting motion of the body's center of gravity. Optimum method to realize these SPT gaits is also discussed. The validity of the considerations is successfully demonstrated by the gait control experiments using the constructed quadruped walking vehicle named TITAN III.
\end{abstract}

ABSTRACT

Key words : Mobile robot, Quadruped walking vehicle, Gait control, Standing posture transformation.

* Received January 23, 1986

** Faculty of Engineering, Mechanical Engineering Laboratory

*** Robotics Department, Mechanical Engineering Laboratory 